\title{
ANALISIS PENGARUH PENGGUNAAN ABU JERAMI TERHADAP KUAT TEKAN BETON
}

\author{
Syibral Malasyi ${ }^{1)}$, Wesli ${ }^{2)}$ Fasdarsyah $^{3)}$ \\ Jurusan Teknik Sipil, Fakultas Teknik, Universitas Malikussaleh \\ email: ${ }^{l)}$ syibral_m@yahoo.co.id ${ }^{2)}{ }^{2}$ r_wesli@yahoo.co.id
}

\begin{abstract}
Abstrak
Abu jerami padi merupakan limbah dari hasil pertanian yang mengandung unsur silica yang dapat dimanfaatkan untuk bahan subtitusi parsial semen dalam campuran beton. Unsur silica dalam semen sebesar $20 \%$ sedangkan unsur silica dalam abu jerami sebesar $65,92 \%$. Penelitian ini bertujuan untuk bahan subtitusi parsial semen dan dengan Penggunaan abu jerami padi diharapkan dapat dipakai dalam pembuatan beton dengan biaya yang relatif murah. Dalam Penelitian digunakan metode SNI dengan jumlah benda uji adalah sebanyak 18 buah. Penambahan abu jerami padi terhadap massa semen sebesar 5\%, 10\%, 15\%, $20 \%$ dan $25 \%$ dari volume semen. Benda uji dilakukan pengujian setelah dilakukan perawatan selama 28 hari. Pada penambahan abu jerami padi sebesar $0 \%$ didapat nilai kuat tekan tekan sebesar 24,53 Mpa, sedangkan dengan penambahan abu jerami 5\% didapat nilai kuat tekan sebesar 21,04 Mpa, penambahan abu jerami $10 \%$ didapat nilai kuat tekan sebesar 17,17 Mpa, penambahan abu jerami $15 \%$ didapat nilai kuat tekan sebesar 16,61 Mpa, penambahan abu jerami $20 \%$ didapat nilai kuat tekan sebesar 15,66 Mpa, dan penambahan abu jerami $25 \%$ didapat nilai kuat tekan sebesar 15,66 Mpa. Semakin banyak penambahan abu jerami padi sebagai bahan subtitusi parsial semen dalam campuran beton, nilai kuat tekan semakin menurun, tetapi pada penggunaan abu jerami $25 \%$ terhadap massa semen masih bisa digunakan untuk beton non struktural.
\end{abstract}

Kata Kunci : Beton, kuat tekan, Abu Jerami padi.

\section{Pendahuluan}

Beton merupakan campuran dari material yang diperoleh dengan membuat campuran dengan proporsi semen, agregat halus, agregat kasar dan air untuk membuat campuran menjadi keras dalam cetakan sesuai dengan bentuk dan dimensi struktur yang diinginkan dan sebagai bahan pembantu guna untuk keperluan reaksi kimia selama proses pengerasan dan perawatan beton berlangsung. Pada pembuatan beton normal yang mempunyai kuat tekan antara 17-40 MPa, umumnya dengan menggunakan kerikil/batu pecah sebagai agregat kasar dan pasir sebagai agregat halus. Semen merupakan bahan yang berfungsi untuk merekatkan material-material di dalam beton di mana kandungan semen dalam suatu campuran beton umumnya berkisar antara 25\%-40\%. Material semen pada saat ini sering menimbulkan banyak masalah yaitu biaya yang relatif mahal dan kadangkala sulit mendapatkannya. Salah satu upaya untuk mengurangi penggunaan semen dalam beton adalah dengan meminimalkan penggunaan semen dalam beton dengan menggunakan abu yang memiliki sifat-sifat pozzolan yaitu sifat yang memiliki bahan yang mengandung silica dan alumina, seperti: abu jerami, abu kelapa sawit, abu sekam padi, flay ash, dan silica fume. 
Dalam penelitian ini digunakan abu jerami sebagai bahan subtitusi parsial semen dalam campuran beton, dan diharapkan dapat meningkatkan mutu beton, dan juga ramah lingkungan. Jerami adalah tanaman padi yang telah diambil bulirnya (gabahnya) sehingga tinggal batang dan daunnya yang merupakan limbah pertanian terbesar di beberapa daerah di Indonesia, jerami biasanya diangkut seluruhnya untuk pakan ternak. Jerami padi merupakan limbah padat yang dihasilkan dari lahan pertanian masyarakat. Abu jerami berasal dari batang padi dan daun padi yang sudah tidak dipergunakan lagi kemudian ditumbuk halus dan dibakar.

Permasalahan dalam penelitian ini adalah seberapa besar pengaruh persentase abu jerami padi bisa digunakan secara bersamaan dengan semen untuk mencapai kuat tekan yang direncanakan dan Seberapa besar kekuatan beton dengan komposisi campuran abu jerami pada 0\%, 5\%, 10\%, 15\%, 20\% dan $25 \%$. Tujuan penelitian ini ingin mengetahui Seberapa besar kuat tekan beton dengan menggunakan abu jerami padi sebagai bahan subtitusi parsial semen dengan beton normal dan seberapa besar komposisi optimum abu jerami padi dalam campuran beton dengan kuat tekan rencana f'c $20 \mathrm{Mpa}$ dan abu jerami padi yang digunakan lolos saringan no. $200 \mathrm{~mm}$. metode yang digunakan dengan membuat benda uji dengan campuran sesuai syarat yang ditentukan SNI.

\section{Tinjauan Kepustakaan}

\subsection{Beton}

Menurut Mulyono (2004), beton merupakan fungsi dari bahan penyusunnya yang terdiri dari bahan semen hidrolis (portland cement), agregat kasar, agregat halus, air dan dengan menggunakan atau tidak bahan tambah (admixture atau additif). Beton pada umumnya mengandung rongga udara sekitar 1\%-2\%, pasta semen (semen dan air) sekitar 25\%-40\% dan agregat (agregat halus dan kasar) sekitar 60\%-75\%. Hasil dari pencampuran antara semen, air, dan agregat halus dan agregat kasar sehingga membetuk massa keras yang disebut dengan beton.

\subsection{Semen Portland}

Menurut Sagel (1997), fungsi utama semen adalah sebagai perekat. Bahanbahan semen terdiri dari batu kapur (gamping) yang mengandung senyawa: Calsium Oksida $(\mathrm{CaO})$, lempung atau tanah liat (clay) adalah bahan alam yang mengandung senyawa: Silika Oksida ( $\mathrm{SiO} 2)$, Aluminium Oksida (Al2O3), Besi Oksida (Fe2O3) dan Magnesium Oksida (MgO).

Menurut Anonim 6, semen portland dapat diklasifikasikan beberapa jenis yaitu:

a. Jenis I yaitu, semen portland untuk penggunaan umum yang tidak memerlukan persyaratan-persyaratan khusus seperti yang disyaratkan pada jenis-jenis lain.

b. Jenis II yaitu, semen portland yang dalam penggunaannya memerlukan ketahanan terhadap sulfat atau kalor hidrasi sedang.

c. Jenis III yaitu, semen portland yang dalam penggunaannya memerlukan kekuatan tinggi pada tahap permulaan setelah pengikatan terjadi. 
d. Jenis IV yaitu, semen portland yang dalam penggunaannya memerlukan kalor hidrasi rendah.

e. Jenis $\mathrm{V}$ yaitu, semen portland yang dalam penggunaanya memerlukan ketahanan tinggi terhadap sulfat.

\subsection{Syarat - Syarat Mutu Semen Portland}

Menurut Anonim 6, Untuk memenuhi mutu yang baik, maka dalam semen Portland harus terkandung beberapa unsur kimia. Persyaratan kimia semen Portland harus memenuhi persyaratan seperti diperlihatkan pada Tabel 1 berikut:

Tabel 1 syarat kimia utama

\begin{tabular}{|c|c|c|c|c|c|c|}
\hline \multirow{2}{*}{ No } & \multirow[b]{2}{*}{ Uraian } & \multicolumn{5}{|c|}{ Jenis sement porland } \\
\hline & & $\mathrm{I}$ & II & III & IV & $\mathrm{V}$ \\
\hline 1 & $\mathrm{SiO}_{2}$, minimum & - & $20,0^{b, c)}$ & - & - & - \\
\hline 2 & $\mathrm{Al}_{2} \mathrm{O}_{3}$, maksimum & - & 6,0 & - & - & - \\
\hline 3 & $\mathrm{Fe}_{2} \mathrm{O}_{3}$, maksimum & - & $6,0^{b, c)}$ & - & 6,5 & - \\
\hline 4 & $\mathrm{MgO}$, maksimum & 6,0 & 6,0 & 6,0 & 6,0 & 6,0 \\
\hline 5 & $\begin{array}{l}\mathrm{SO}_{3}, \text { maksimum } \\
\text { Jika } \mathrm{C}_{3} \mathrm{~A} \leq 8,0 \\
\text { Jika } \mathrm{C}_{3} \mathrm{~A}>8,0\end{array}$ & $\begin{array}{l}3,0 \\
3,5\end{array}$ & $\begin{array}{l}3,0 \\
\text { d) }\end{array}$ & $\begin{array}{r}3,5 \\
4,5\end{array}$ & $\begin{array}{l}2,3 \\
\text { d) }\end{array}$ & $\begin{array}{c}2,3 \\
\text { d) }\end{array}$ \\
\hline 6 & Hilang pijar, maksimum & 5,0 & 3,0 & 3,0 & 2,5 & 3,0 \\
\hline 7 & Bagian tak larut, maksimum & 3,0 & 1,5 & 1,5 & 1,5 & 1,5 \\
\hline 8 & $\mathrm{C}_{3} \mathrm{~S}$, maksimum $^{\text {a) }}$ & - & - & - & $35^{\text {b) }}$ & - \\
\hline 9 & $\mathrm{C}_{2} \mathrm{~S}$, minimum $^{\text {a) }}$ & - & - & - & $40^{\text {b) }}$ & - \\
\hline 10 & $\mathrm{C}_{3} \mathrm{~A}$, maksimum $^{\text {a) }}$ & - & 8,0 & 1,5 & $7^{b)}$ & $5^{b)}$ \\
\hline 11 & $\begin{array}{l}\mathrm{C}_{4} \mathrm{AF}+2 \mathrm{C}_{3} \mathrm{~A} \text { atau } \\
\mathrm{C}_{4} \mathrm{AF}+\mathrm{C}_{2} \mathrm{~F}, \text { maksimum }^{2}\end{array}$ & - & - & - & - & $25^{c)}$ \\
\hline
\end{tabular}

Sumber: Anonim 6 (2004)

\subsection{Agregat Halus}

Menurut Anonim 4, agregat halus adalah pasir alam sebagai hasil disintergrasi alami batuan atau pasir yang dihasilkan oleh industri pemecah batu dan mempunyai ukuran butir terbesar 4,75 mm (No.4).

Tabel 2. Gradasi Agregat Halus

\begin{tabular}{|c|c|c|}
\hline $\begin{array}{c}\text { Diameter Saringan } \\
(\mathrm{mm})\end{array}$ & $\begin{array}{c}\text { Persen Lolos } \\
(\%)\end{array}$ & $\begin{array}{c}\text { Gradasi Ideal } \\
(\%)\end{array}$ \\
\hline 9,50 & 100 & 100 \\
\hline 4,75 & $95-100$ & 97,5 \\
\hline 2,36 & $80-100$ & 90 \\
\hline 1,18 & $50-85$ & 67,5 \\
\hline 0,600 & $25-60$ & 42,5 \\
\hline 0,300 & $10-30$ & 17,5 \\
\hline 0,150 & $2-10$ & 5 \\
\hline
\end{tabular}

Sumber: Anonim 4 (2002) 


\subsection{Agregat Kasar}

Menurut Anonim 3, agregat kasar adalah pasir alam sebagai hasil di sintergrasi alami batuan atau pasir yang dihasilkan oleh industri pemecah batu dan mempunyai ukuran butir antara 4,75 mm (No.4) sampai $40 \mathrm{~mm}$ (No. $1^{1 / 2}$ inchi).

Tabel 3 persyaratan batas-batas susunan besar butir agregat kasar (kerikil)

\begin{tabular}{|c|c|c|c|}
\hline \multirow{2}{*}{ Ukuran Mata Ayakan (mm) } & \multicolumn{3}{|c|}{ Persentase berat bagian yang lewat ayakan } \\
\cline { 2 - 4 } & \multicolumn{3}{|c|}{ Ukuran nominal agregat (mm) } \\
\hline & $38-4,76$ & $19,0-4,76$ & $9,6-4,76$ \\
\hline 38,1 & $95-100$ & 100 & - \\
\hline 19,0 & $37-70$ & $95-100$ & 100 \\
\hline 9,52 & $10-40$ & $30-60$ & $50-85$ \\
\hline 4,76 & $0-5$ & $0-10$ & $0-10$ \\
\hline
\end{tabular}

Sumber: Anonim 3 (2000)

\subsection{Air}

Menurut Anonim 5, air yang digunakan pada campuran beton harus bersih dan bebas dari bahan-bahan merusak yang mengandung oli, asam, alkali, garam, bahan organic, atau bahan-bahan lainnya yang merugikan terhadap beton. Air pada beton mempunyai fungsi sebagai pengencer. Agar cairan beton dapat padat dan mengisi ruang-ruang sehingga membentuk cetakan. Ciri-ciri air yang baik untuk campuran beton adalah tidak berwarna, tidak berbau dan tidak berasa Air sangat diperlukan dalam pembuatan beton, beton tidak akan terbentuk tanpa adanya air sebagai campuran. Karena semen tidak akan bereaksi dan menjadi pasta apabila tidak ada air.

\subsection{Bahan Subtitusi Parsial Semen, Abu Jerami padi}

Menurut El-Sayed (2006), Abu jerami padi berasal dari jerami yang digiling atau ditumbuk halus. Abu jerami padi dapat dimanfaatkan untuk abu gosok, bahan ameliorasi tanah asam dan bahan campuran dalam pembuatan semen hidrolik serta dapat dimanfaatkan campuran batako/mortar, beton, dan campuran batu bata press.

Tabel 4. komposisi pada abu jerami padi

\begin{tabular}{|c|c|}
\hline Kimia & Berat dalam persen \\
\hline $\mathrm{SiO}_{2}$ & 65,92 \\
$\mathrm{AL}_{2} \mathrm{O}_{3}$ & 1,78 \\
$\mathrm{Fe}_{2} \mathrm{O}_{3}$ & 0,20 \\
$\mathrm{CaO}$ & 2,4 \\
$\mathrm{MgO}$ & 3,11 \\
$\mathrm{SO}_{4}$ & 0,69 \\
\hline
\end{tabular}

Sumber: El-Sayed (2006)

\subsection{Kuat tekan beton}

Menurut Mulyono (2004), bahwa kuat tekan beton adalah kemampuan beton untuk menerima gaya tekan persatuan luas. Rumus yang digunakan untuk perhitungan kuat tekan beton adalah sebagai berikut: 


$$
f=\frac{P}{A}
$$

di mana:

$\mathrm{f}=$ Kuat tekan $\left(\mathrm{kg} / \mathrm{cm}^{2}\right)$

$\mathrm{P}=$ Gaya tekan $(\mathrm{kg})$

$\mathrm{A}=$ Luas penampang benda uji $\left(\mathrm{cm}^{2}\right)$

\section{$3 \quad$ Metode Penelitian}

Penelitian ini dilakukan di Laboratorium Jurusan Teknik Sipil, Fakultas Teknik, Universitas Malikussaleh. Tahapan penelitian ini meliputi persiapan, pelaksanaan, dan analisis data. Pada tahap persiapan, penelitian ini dimulai dengan permasalahan, ide studi kemudian dilanjutkan dengan persiapan dan pengadaan bahan dan pengujian karakteristik dan analisis fisik material, yaitu: agregat halus, agregat kasar, semen portland, air dan bahan subtitusi parsial semen (abu jerami padi). Sedangkan tahap pelaksanaan, dilakukan mix design, pembuatan beton, perawatan beton, dan kemudian pengujian beton. Untuk pembuatan beton abu jerami padi yang dicampur terhadap massa semen berkisar $(5 \%, 10 \%, 15 \%, 20 \%$ dan $25 \%)$, dan kemudian dicetak dalam cetakan selinder. Setelah 24 jam cetakan beton dibuka, lalu dilakukan perendaman sampel beton selama 28 hari. Kemudian dilakukan pengujian kuat tekan beton, dan dihitung kuat tekan. Untuk tahap analisis, data yang diperoleh dari hasil pengujian kuat tekan selanjutnya dianalisa. Setelah semua data tersebut dianalisa maka dilakukan pembahasan terhadap hasil analisa dan dapat diambil kesimpulan.

Sebelum dilaksanakan mix design terlebih dahulu dipersiapkam materialmaterial yang dicampur dalam campuran beton antara lain: Semen Portland tipe II (Semen Andalas Indonesia), agregat kasar yang berasal dari Krueng Sawang, agregat halus yang berasal dari Krueng Mane, air yang berasal dari sumur Bukit Indah dan bahan subtitusi parsial semen (abu jerami padi) yang berasal dari Desa Reulet Barat Kecamatan Dewantara Kabupaten Aceh Utara. Setelah semua material didapatkan kemudian dilakukan penelitian di Laboratorium Teknik Sipil Universitas Malikussaleh Kabupaten Aceh Utara.

Tabel 1 Jumlah dan Variasi Benda Uji

\begin{tabular}{|c|c|c|c|c|}
\hline No & Nama Benda Uji & $\begin{array}{c}\text { Variasi } \\
(\%)\end{array}$ & Jumlah Kuat Tekan & $\begin{array}{c}\text { Jumlah } \\
\text { Total }\end{array}$ \\
\hline 1 & A0a, A0b, A0c, & 0 & 3 & 3 \\
\hline 2 & A5a, A5b, A5c, & 5 & 3 & 3 \\
\hline 3 & A10c, A10b, A10c, & 10 & 3 & 3 \\
\hline 4 & A15a, A15b, A15c, & 15 & 3 & 3 \\
\hline 5 & A20a, A20b, A20c, & 20 & 3 & 3 \\
\hline 6 & A25a, A25b, A25c, & 25 & 3 & 3 \\
\hline \multicolumn{5}{|c|}{ Jumlah Benda Uji } \\
\hline
\end{tabular}

Benda uji dibuat sebanyak 18 buah benda uji, yang berbentuk silinder dengan diameter $15 \mathrm{~cm}$ dan tinggi $30 \mathrm{~cm}$. Benda uji dibiarkan dalam cetakan silinder selama 1 hari (24 jam), setelah dibuka dari cetakan benda uji langsung 
dibawa ke tempat perawatan/perendaman. Proses perawatan dilakukan dengan memasukkan benda uji kedalam bak yang berisi air. Benda uji diletakkan didalam air hingga semua permukaannya terendam dengan sempurna. Perendaman ini dilakukan sesuai dengan umur perawatan yang telah direncanakan yaitu selama 28 hari.

\section{Hasil dan Pembahasan}

\subsection{Hasil pengujian kuat tekan beton}

Beton berbentuk silinder dengan ukuran $30 \mathrm{~cm}$ x $15 \mathrm{~cm}$ yang dilakukan pengujian kuat tekan beton pada umur 28 hari. Kuat tekan beton menggambarkan mutu dari sebuah struktur, semakin tinggi tingkat kekuatan struktur yang di capai, maka mutu beton yang akan dihasilkan lebih tinggi juga. Besarnya yang didapat dari masing-masing persentase pemakaian abu jerami padi yaitu, untuk pemakaian $0 \%$ abu jerami padi didapat nilai kuat tekan 24,53 Mpa, untuk pemakaian abu jerami padi 5\% didapat nilai kuat tekan beton 21,04 Mpa, untuk $10 \%$ abu jerami padi didapat nilai kuat tekan beton $17,17 \mathrm{Mpa}$, untuk Pemakaian $15 \%$ abu jerami padi didapat nilai kuat tekan beton 16,61 Mpa, untuk pemakaian abu jerami padi $20 \%$ didapat nilai kuat tekan beton 15,66 Mpa, dan untuk pemakaian abu jerami padi $25 \%$ didapat nilai kuat tekan 15,66 Mpa.

Pengaruh penggunaan abu jerami padi sebagai bahan subtitusi parsial semen terhadap kuat tekan beton dengan umur pengujian 28 hari. Untuk lebih jelas dapat dilihat pada gambar 1 .

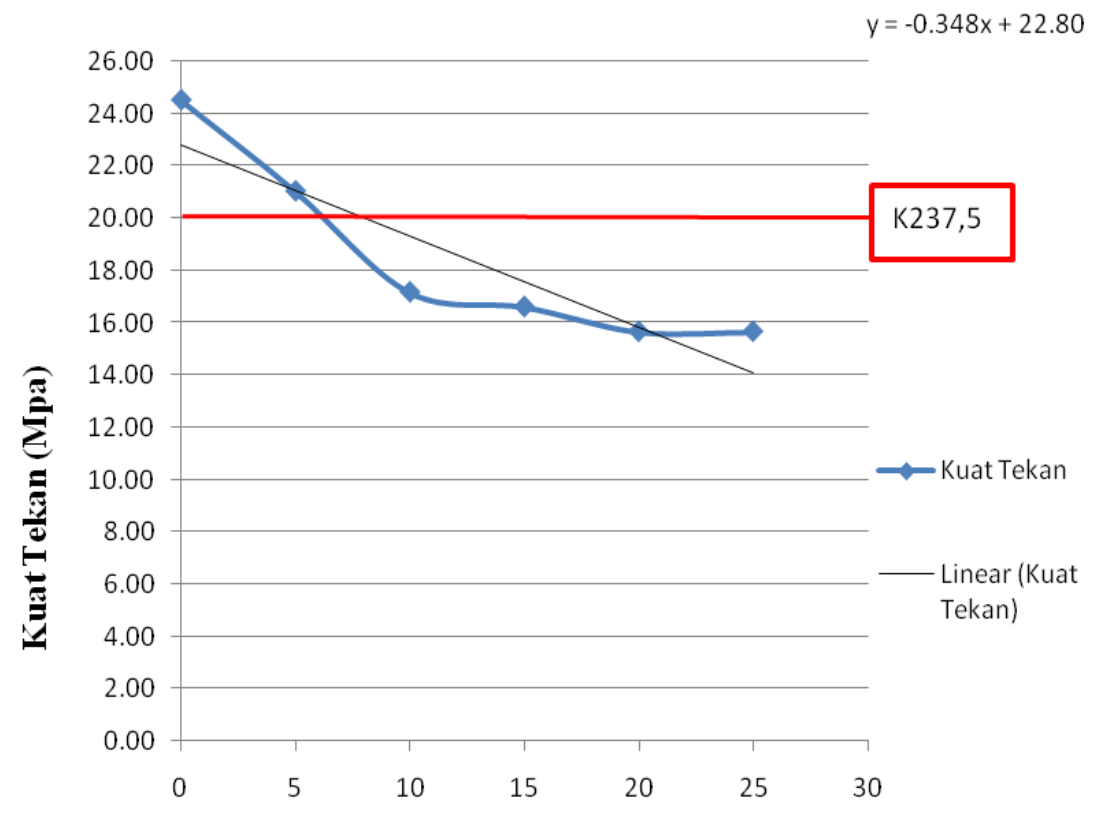

Persentase Abu Jerami (\%)

Gambar 1 Hubungan Kuat Tekan Beton dengan Prosentase Abu Jerami 
Dari Gambar 1 didapat hasil bahwa semakin banyak persentase pemakaian abu jerami padi dalam campuran beton maka semakin menurun kuat tekan beton.

\subsection{Pembahasan pengujian kuat tekan beton}

Dari hasil pengujian didapat bahwa penggunaan abu jerami sebagai bahan subtitusi parsial semen dalam campuran beton sangat berpengaruh terhadap kuat tekan beton. Dengan tanpa penggunaan abu jerami padi diperoleh nilai kuat tekan beton sebesar 24,53 Mpa, dengan penggunaan abu sebesar 5\% didapat nilai kuat tekan sebesar 21,04 Mpa sehingga terjadi penurunan kuat tekan sebesar 14,23\% dari kuat tekan beton normal. Dengan pemakaian abu jerami sebesar 10\% didapat nilai kuat tekan sebesar 17,17 Mpa terjadi penurunan kuat tekan sebesar 30\%, dengan pemakaian abu jerami sebesar 15\% didapat nilai kuat tekan sebesar 17,61 Mpa terjadi penurunan kuat tekan sebesar $32,29 \%$, dengan pemakaian abu jerami sebesar 20\% didapat nilai kuat tekan sebesar 15,61 Mpa, terjadi penurunan kuat tekan sebesar $36,37 \%$, dan dengan pemakaian abu jerami sebesar $25 \%$ didapat nilai kuat tekan sebesar 15,61 Mpa, terjadi penurunan kuat tekan sebesar 36,37\%. Berdasarkan hasil perhitungan dapat disimpulkan bahwa persentase optimum abu jerami padi terhadap berat volume semen kuat tekan beton tidak diperoleh sesuai yang direncanakan, karena semakin tinggi kandungan abu jerami padi dalam campuran beton, kuat tekan beton semakin menurun. Dalam penelitian terdahulu yang dilakukan oleh Devi Marwina (2009), penggunaan abu jerami kuat tekan meningkat pada pemakaian abu jerami sebesar 15\% tetapi dilakukan dalam campuran pembuatan mortar, diduga meningkat karena dalam campuran mortar tetapi bukan dalam campuran beton. pada persentase $25 \%$ penggunaan abu jerami terhadap massa semen masih bisa digunakan untuk beton non struktural. untuk lebih jelas diperlihatkan pada gambar 1 .

\section{$5 \quad$ Kesimpulan dan Saran}

\subsection{Kesimpulan}

Dari hasil penelitian yang telah dilakukan dapat diambil beberapa kesimpulan sebagai berikut :

1. Nilai kuat tekan beton tidak berpengaruh dengan penggunaan abu jerami padi bersamaan dengan semen karena nilai kuat tekan dengan penggunaan abu jerami padi beton menurun dibandingkan dengan nilai kuat tekan beton tanpa menggunakan abu jerami padi.

2. Komposisi optimum abu jerami padi dalam campuran tidak bisa didapat, karena semakin banyak penambahan abu jerami padi dalam campuran beton nilai kuat tekan beton semakin menurun.

3. Pada beton normal didapat nilai kuat tekan beton sebesar 24,53 Mpa sedangkan pada penambahan abu jerami 5\% didapat sebesar 21,04 Mpa, 10\% abu jerami didapat nilai kuat tekan sebesar 17,17 Mpa, 15\% abu jerami didapat nilai kuat tekan sebesar 16,61 Mpa, 20\% abu jerami didapat nilai kuat tekan sebesar 15,56 Mpa, dan dengan penambahan 25\% abu jerami didapat nilai kuat tekan sebesar 15,56 Mpa,

4. Berdasarkan persamaan regresi linier dengan menggunakan metode numerik kuat tekan yang masih dalam batasan yang direncanakan yaitu pada variasi 8 $\%$ abu jerami padi dengan kuat tekan beton 20,008 Mpa.

Analisis Pengaruh Penggunaan Abu Jerami Terhadap Kuat Tekan Beton - Syibral Malasyi, Wesl, Fasdarsyah 


\subsection{Saran}

Dari hasil penelitian kuat tekan beton dengan campuran abu jerami dengan perbandingan pada beton normal dapat diberikan beberapa saran antara lain:

1. Perlu dilakukan penelitian lanjutan tentang pemakaian abu jerami padi sebagai bahan subtitusi parsial semen menggunakan variasi $1 \%-5 \%$.

2. Untuk pembakarannya abu jerami padi dengan menggunakan tempat pembakaran khusus yang ada pengaturan suhu pembakaran dan dengan penambahan zat additive karena sangat berpengaruh terhadap hasil nilai kuat tekan beton.

3. Pada penelitian lanjutan tentang beton agar lebih diperhatikan dalam penggunaan material, gradasi agregat dan harus sangat teliti pada perencanaan mix design kemudian dalam pengecoran sampai perawatan dan pengujian beton.

4. Selain abu jerami padi, bahan substitusi parsial semen yang dapat dimanfaatkan dalam campuran beton seperti: abu sekam padi, abu tras, flay ash, abu kelapa sawit, abaka, dan silica fume.

\section{Daftar Kepustakaan}

Anonim 1, 1990, SNI 03-1974-1990, Metode pengujian kuat tekan beton, BSNI, Jakarta.

Anonim 2, 1993, SNI 03-2834-1993, Tata Cara Pembuatan Rencana Campuran beton Normal, BSNI, Jakarta.

Anonim 3, 2000, SNI 03-2834-2000, Mix Design, BSNI, Jakarta.

Anonim 4, 2002, ASTM, Standard Specification For Concrete Aggregates, Department Of Defense, United states.

Anonim 5, 2002, SNI 03-2847-2002, Tata Cara Perhitungan Beton Untuk Gedung, BSNI, Jakarta.

Anonim 6, 2004, SNI 15-2049-2004, Semen Portland, BSNI, Jakarta.

Anonim 7, 2007, SNI DT-91-0008-2007, Tata Cara Perhitungan HARGA Satuan Pekerjaan Beton, Departemen Pekerjaan Umum, Jakarta.

Anonim 8, 2008, SNI 1970-2008, Cara uji berat jenis dan penyerapan air agregat halus, BSNI, Jakarta.

Anonim 9, 2012, Modul Praktikum Teknologi Bahan Kontruksi Laboratorium Teknik Sipil Universitas Malikussaleh, Lhokseumawe.

Anni Susilowati, 2010. Abu batubara sebagai bahan pengganti semen sebagian dalam mortar, Jurusan Teknik Sipil Politeknik Negeri Jakarta.

Devi Marwina, 2009. Pemanfaatan abu jerami padi sebagai pencampur semen pada pembuatan mortar, Jurusan Fisika Universitas Sumatra Utara.

Analisis Pengaruh Penggunaan Abu Jerami Terhadap Kuat Tekan Beton - Syibral

Malasyi, Wesl, Fasdarsyah 
Ermiyati, 2007. Abu kelapa sawit sebagai pengganti sebagian semen terhadap kuat tekan dan resapan air pada mortar, Jurusan Teknik Sipil Universitas Riau.

Ermiyati dan Jhon Hafni, 2007. Abu sekam padi sebagai pengganti sebagian semen pada beton, Jurusan Teknik Sipil Universitas Riau.

El-Sayed, 2006. Physical and chemical pro`perty of rice straw ash and its effect on the cement paste produced from different cemen types, Jurusan Teknik Sipil Universitas Minofiya Egypt.

Fathmah Mahmud, 2007. Optimasi campuran material pozzolan abu bata apung dan silica fume sebagai bahan pengganti semen pada beton mutu tinggi, Jurusan Teknik Sipil Universitas Mataram.

Khairul Lakum. C, 2009. Pemanfaatan abu sekam padi sebagai campuran untuk peningkatan kekuatan beton, Fakultas Matematika dan Ilmu Pengetahuan Alam Universitas Sumatera Utara.

Mulyono, 2004. Teknologi Beton, Penerbit Andi, Yogyakarta.

Sagel, R., Kole, P., Kusuma, Gideon H., 1997, Pedoman Pengerjaan Beton, Penerbit Erlangga, Jakarta. 